\title{
ARHEOLOŠKA I POVIJESNA ISTRAŽIVANJA VARAŽDINSKIH UTVRDA
}

$U$ radu se obrađuje aspekt varaždinskih utvrda interpretiran kroz rezultate arheoloških istraživanja i podatke iz povijesnih izvora, te danas očuvane ostatke. Utvrde oko naselja okruživale su grad Varaždin u obliku nepravilna četverokuta, njihov nastanak, prema za sada poznatim povijesnim izvorima, veže se uz ratne opasnosti koje su prijetile stanovništvu od druge polovice 15. st., a srednjovjekovni fortifikacijski supstrat na kojem utvrde nastaju do sada još uvijek nije dovoljno istražen. Kroz 16. st. utvrde doživljavaju modernizaciju u sklopu renesansnog fortifikacijskog sustava. Tijekom 18. st. uslijed urbanističkog razvoja grada izvedene su intervencije na utvrdama oko naselja kada se uz postojeća južna i sjeverna vrata, otvaraju vrata u zapadnom i južnom zidu da bi se naposljetku početkom 19. st. pokrenulo njihovo sustavno rušenje.

\section{UVOD}

Gradska arheologija na području Varaždina dobiva svoj puni zamah tek od 90-ih godina 20. st., iako se arheološki nadzori u gradu sporadično provode i prije tog razdoblja. Slika arheoloških slojeva koji leže ispod suvremenog grada polako se počela otkrivati sa svakim arheološkim nadzorom te tako postupno potvrđivati ili nadopunjavati podatke u povijesnim izvorima. Tako su između ostalog i pronađeni segmenti gradskih renesansnih zidina (murus civitatis) srušenih početkom 19. stoljeća. lako su lokacije njihovih rasprostiranja bile poznate, ono što je utvrđeno arheološkim otkrićima su njihovi točni položaji važni za interpretaciju 
i moguću buduću prezentaciju. Varaždinske utvrde oko naselja obrađivane su u djelima istraživača koji su ih tematizirali vezano uz povijesni razvoj grada Varaždina. ${ }^{1}$ Ono što je uočljivo i sasvim razumljivo, zbog nemogućnosti promatranja izravno na materiji jest oskudnost podataka o utvrdama oko naselja. Upravo iz tog razloga važna je gradska arheologija koja te podatke nadopunjuje.

Osmanska opasnost uvelike je utjecala na razvoj grada Varaždina koji je zbog istaknutog položaja u obrani Hrvatskog kraljevstva, ali i čitave Štajerske morao biti bolje utvrđen. ${ }^{2}$ Bio je potreban veliki građevinski zahvat čime bi se plemićka utvrda i naselje povezali zajedničkim fortifikacijskim sustavom. Zbog toga se na poticaj štajerskih staleža sredinom 16. st. paralelno s modernizacijom srednjovjekovne plemićke utvrde u renesansni Wasserburg grade i moderniziraju gradske zidine na trasama ranijih palisada. ${ }^{3}$ Time su utvrde oko naselja i utvrda plemićkog grada postale jedinstveni fortifikacijski sustav.

Srednjovjekovnu podlogu na kojoj je nastao sustav renesansnih gradskih utvrđenja još uvijek je teško arheološki potvrditi i rekonstruirati. ${ }^{4}$ Srednjovjekovna utvrđenja u zasad poznatim povijesnim izvorima spominju se već 1454. godine kada se bilježi odluka da gradski sudac mora kazniti svakog tko uništava gradske palisade (sepes) i opkope (fossata). ${ }^{5}$ Pretpostavlja se da je sredinom 15. st. Varaždin bio utvrđen nasipima i drvenim palisadama te opkopima s vodom, a kada je točno započela gradnja zidanih fortifikacija nakon toga, nije do sada poznato. Rudolf Horvat navodi da je gradnja utvrda oko naselja započela odmah nakon požara 1446. godine, ali bez točnih podataka o povijesnim izvorima

1 Spomenka TEŽAK, "Varaždinska gradska utvrđenja”, Izdanja Hrvatskog arheološkog društva, 28, Zagreb, 2012., 259-262.

2 Mirela SLUKAN ALTIĆ, "Razvoj i gradnja Varaždina u 16. st., Urban development of Varaždin in the 16th century", Podravina, Volumen VII, broj 14, Koprivnica, 2008., 75-79.

3 Mira ILIJANIĆ, "Prilog istraživanju renesansne pregradnje varaždinske tvrđe u 16. st.", Godišnjak gradskog muzeja Varaždin, br. 1, 1961., 33-43.; Mira ILIJANIĆ, "Prilog historijsko urbanističkoj dokumentaciji Varaždina od postanka do 16.st.", Peristil: Zbornik radova za povijest umjetnosti, Vol. 6-7, No. 1, 1963., 26.; Ivy LENTIĆ-KUGLI, Povijesna urbana cjelina grada Varaždina, Zagreb, 1977., 28-31.; Mirela SLUKAN ALTIĆ, Povijesni atlas gradova-Varaždin (sv.5), Zagreb - Varaždin, 2009., 63-66.

4 Stjepan Vuković u svom terenskom dnevniku spominje ostatke drvenih pilona dokumentiranih 1960. godine u iskopu za vodovod u Ulici Andrije Kačića Miošića. Piloni, vjerojatno od hrastovine, pronađeni u razmaku od $4 \mathrm{~m}$, promjera 52 i $54 \mathrm{~cm}$ na dubini od $152 \mathrm{~cm}$, postavljeni su u smjeru istok zapad. S obzirom na nedostatak drugih podataka uslijed uvjetovanog arheološkog nadzora nije jasno radi li se o ostatku konstrukcije srednjovjekovnog drvenog utvrđenja ili možda o ostatku skela za potrebe izgradnje ili popravaka oštećenja na gradskim zidinama u 16. st. (Gradski muzej Varaždin, dokumentacija Arheološkog odjela).

5 M. ILIJANIĆ, n. dj., 24-25.; Mira ILIJANIĆ, „Varaždinske gradske zidine, Prilog historijatu našeg grada“, Urbanizam, graditeljstvo kultura, Zbornik radova, Grad Varaždin - Gradski muzej Varaždin, Varaždin, 1999., 157.; M. SLUKAN ALTIĆ, Povijesni atlas gradova-Varaždin, 58. 
iz kojih crpi ta saznanja. ${ }^{6}$ Izvjesno je da se od 1516. godine, nakon odluke kralja Ludovika II. da se kraljevski porez utroši u gradnju gradskih zidina, vrše na njima građevinski radovi. Voditelj radova tada je bio Pankracije Jagersperger, a iz njegovih trogodišnjih izvještaja saznaju se podaci o materijalu i vrsti radova pri gradnji zidina. Spominju se kruništa zidina, krov nadstrešnice i drveni unutarnji hodnici za kretanje vojske, svi elementi vidljivi na veduti Sigismunda Koppa iz albuma Društva Blažene Djevice Marije iz 1732. godine koja grad prikazuje s južne strane (sl. 1). Navodi se visina zida od 3 i 4 klaftre, što bi iznosilo između 5,5. i 7,5 metara. ${ }^{7}$ Ukupna dužina zidina koja je iznosila više od $886 \mathrm{~m}$ izmjerena je prilikom razgradnje u 19. st., s tim da sjeverna strana nije bila uračunata jer je već tada bila razgrađena i dijelom pod kućama. ${ }^{8}$ Od čitavog nekadašnjeg opsega gradskih zidina vidljivi i prezentirani ostaci danas su poprilično oskudni.

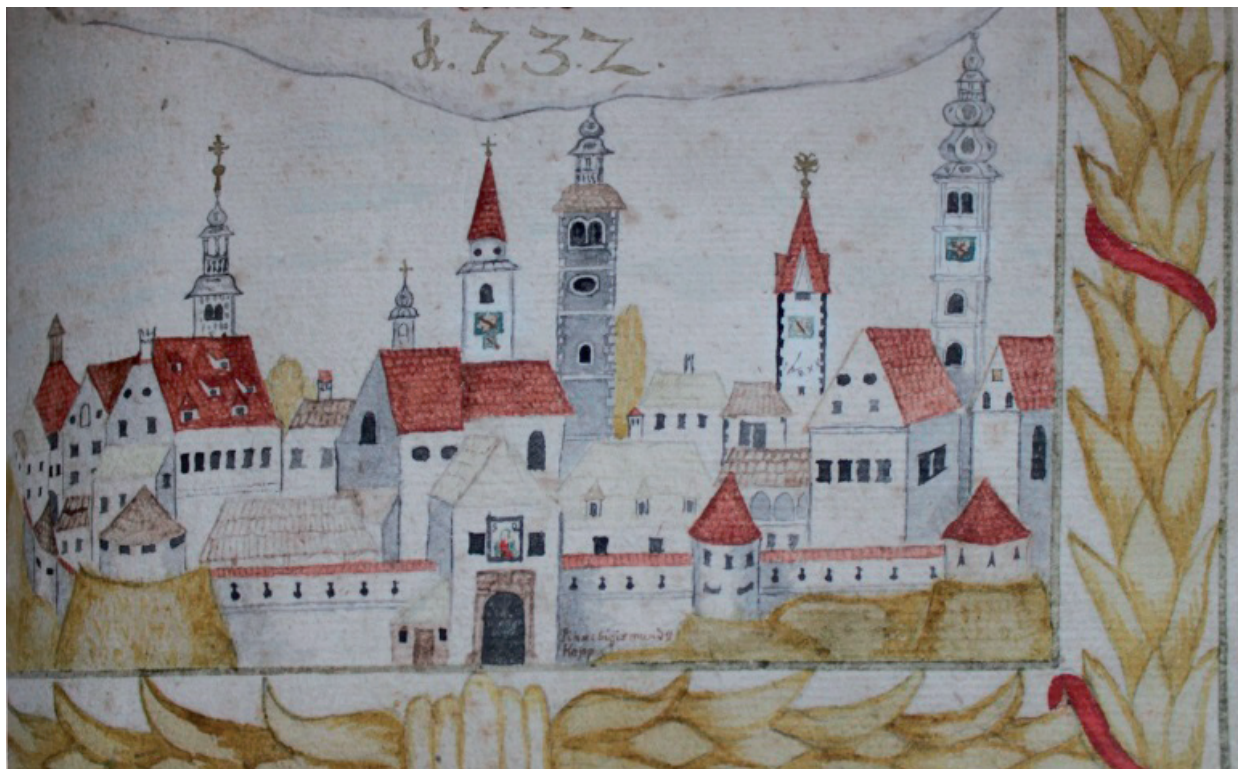

Slika 1. Veduta grada Varaždina iz 1732. godine, autora Sigismunda Koppa, (snimio: Davor Puttar. Gradski muzej Varaždin)

6 Rudolf HORVAT, Povijest grada Varaždina, Hrvatska akademija znanosti i umjetnosti, Zavod za znanstveni rad Varaždin, Varaždin 1993., 24-26.

7 Ljerka PERČl, "Prilog poznavanju izgradnje varaždinskih gradskih utvrda u prvoj četvrtini 16. stoljeća”, Muzejski vjesnik 12, Bjelovar, 1989., 54-56.

8 Marija MIRKOVIĆ, "O spajanju unutarnje varoši i gradskih predgrađa u Varaždinu”, Godišnjak Gradskog muzeja Varaždin, br. 2-3, Varaždin, 1962.-1963., 49. 
Varaždinske utvrde oko naselja svoju su preobrazbu i konačni oblik dosegle u jeku modernizacije u 16. stoljeća9 ${ }^{9}$ Najstariji dosad poznati plan Varaždina djelo je Daniela Specklina iz 1568. godine (sl. 2) koji prikazuje stanje varaždinskih utvrda oko naselja i plemićke utvrde. ${ }^{10}$ Oblik utvrde oko naselja činio je približno kvadratni oblik, uza zidove su zemljani bedemi (terrapieno), duž stranica i na uglovima starije okrugle kule. Jedan manji bastion je na istočnoj stranici, a dva veća bastiona koji su obuhvatili okrugle kule nalaze se na jugozapadnom i jugoistočnom uglu naselja. Na sjeverozapadnom uglu naselja zasebnu cjelinu čini plemićki grad. ${ }^{11}$ Upravo je ovaj oblik utvrđenja odredio način na koji će varaždinska gradska jezgra izgledati i razvijati se u kasnijim stoljećima. Prestankom osmanske opasnosti život će se početi odvijati i izvan gradskih zidina da bi se na kraju 18. st., s obzirom na povećan obim stanovništva, a time i urbanistički razvoj grada, probio istočni i zapadni dio zida. Ubrzo nakon toga počelo se razmišljati i o rušenju gradskih utvrđenja što je na kraju i provedeno početkom 19 . stoljeća. ${ }^{12}$ Rušenje zidina provedeno je sustavno i vrlo temeljito počevši od zapadnog gradskog zida, a prodajom građe i građevinskih zemljišta na mjestima nekadašnje trase zida financirani su daljnji radovi na rušenju i uređenju prostora. Plansko rušenje zahtijevalo je predračune koji donose između ostalog navode o tome da su trase gradskih zidina sačuvane ispod uličnog horizonta. ${ }^{13}$ Ovakav podatak zanimljiv je arheološki jer se na pretpostavljenim trasama mogu otkriti ostaci gradskih zidina što je uostalom i potvrđeno pojedinim arheološkim nadzorima.

9 Više o radovima na modernizaciji utvrde koju vodi Domenico dell' Allio u: Spomenka TEŽAK, "Pisani dokumenti o gradnji sustava obrane varaždinske utvrde Stari grad", Iz srednjega u novi vijek - varaždinski Stari grad i projekt Bastion, Katalog izložbe, Varaždin, 2008., 5-12.

10 Miroslav KLEMM, "Planovi i vedute Varaždina", Iz srednjega u novi vijek - varaždinski Stari grad $i$ projekt Bastion, Katalog izložbe, Varaždin, 2008., 13-14.; M. SLUKAN ALTIĆ, n. dj., 78-82.

11 Andrej ŽMEGAČ, Bastioni kontinentalne Hrvatske, Institut za povijest umjetnosti, Zagreb, 2000., 160-161.

12 M. MIRKOVIĆ, n. dj., 45-50.; Rudolf HORVAT, Povijest grada Varaždina, 280-281.

13 M. MIRKOVIĆ, n. dj., 48-49. 

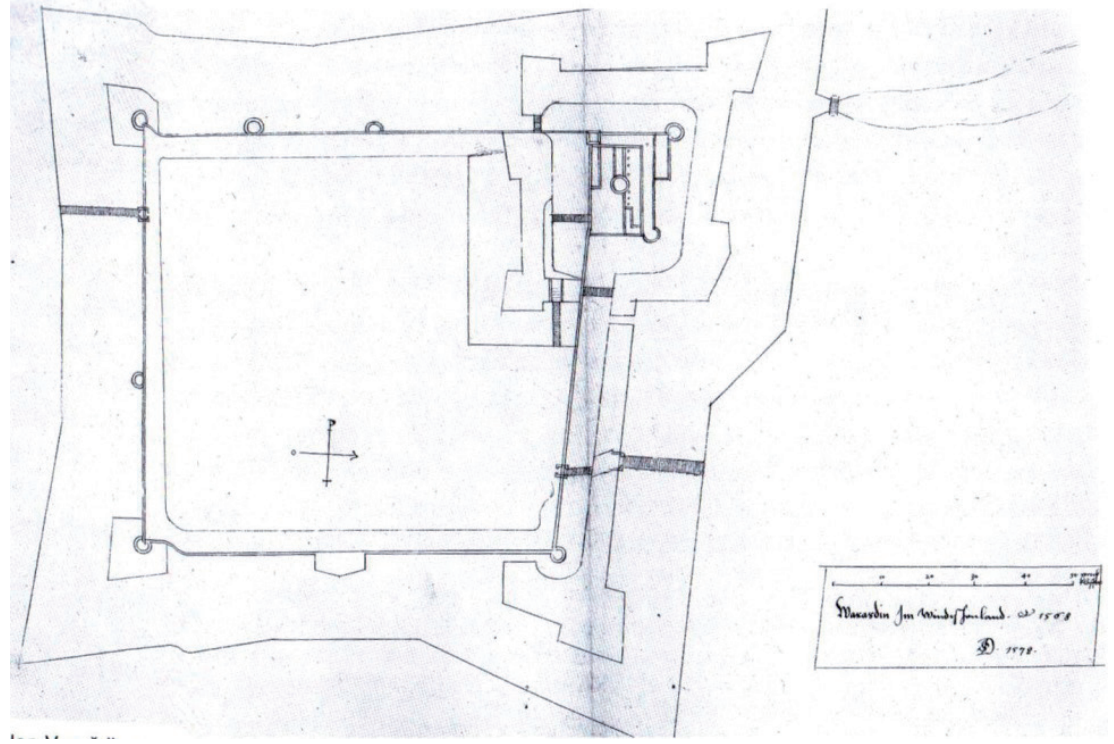

Slika 2. Crtež Varaždina iz 1568. godine, autora Daniela Specklina (prema: Slukan Altić, 2008: 78)

\section{ZAPADNI GRADSKI ZID}

Zapadni gradski zid prvi je puta otkriven još 1941. godine (sl. 3) prilikom uređenja okoliša parka Staroga grada i popravka oštećenog zemljanog bedema. ${ }^{14}$ Nakon toga je zatrpan te je ispitan tek za vrijeme sustavnih arheoloških istraživanja u okviru projekta Bastion 2006. godine kada je istraživana obrambena cjelina feudalnog kompleksa Starog grada. ${ }^{15}$ Zid je sačuvan u dužini od 20-ak m, prosječne širine $120 \mathrm{~cm}$, građen je od lomljenog kamena vezanog žbukom. Jedan njegov dio se nalazi u južnom zemljanom bedemu Starog grada, dok se drugi proteže prema zgradi žitnice, što je i vidljivo na planu Daniela Speklina gdje se i zapadni i sjeverni gradski zid protežu unutarnjim opkopom tvrđave. Zid se uz zgradu žitnice prislanjao na kružnu kulu za koju do sada nije poznato kada je

14 Krešimir FILIĆ, Blagajnička knjiga Povjereničtva za službu rada mladosti, 1941. (GMV dokumentacija Povijesnog odjela).

15 Marina ŠIMEK, Varaždin - Stari grad, arheološko istraživanje 2006. (GMV AO dokumentacija); M. ŠIMEK, "Arheologija bedema i opkopa, Iz srednjega u novi vijek - varaždinski Stari grad i projekt Bastion, Katalog izložbe, Varaždin, 2008., 21-22.; M. ŠIMEK, "Arheološka istraživanja varaždinske utvrde”, Podravina Vol. VII, br. 13, 2008., Koprivnica, 9-10. 
srušena. Arheološki kula još nije potvrđena, a danas je vidljiv na toj poziciji samo kružni povišeni plato. ${ }^{16}$

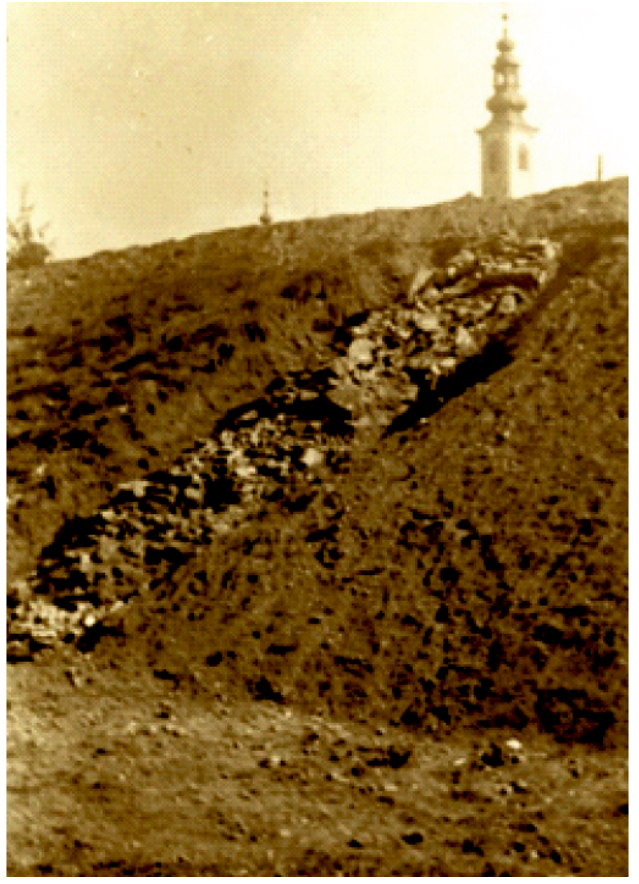

Slika 3. Zapadni gradski zid otkriven 1941. godine (Gradski muzej Varaždin)

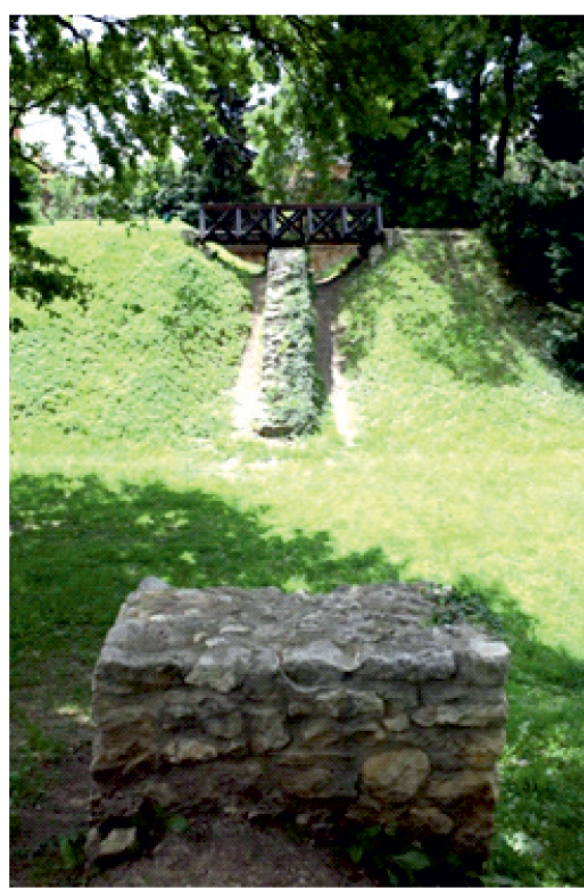

Slika 4. Prezentirani dio zapadnog gradskog zida (snimio: Andrej Švoger. Gradski muzej Varaždin)

Na mjestu današnjeg opkopa nedostaje dio zapadnog gradskog zida koji je vrlo vjerojatno srušen u drugoj polovici 16 st. prilikom kopanja obrambene grabe. Koliko je taj zid stariji od zemljanog bedema ili koliko je istodobno bio s njim u funkciji nažalost nije arheološki potvrđeno. ${ }^{17}$ Zapadni gradski zid jedini je segment gradskog zida koji je konzerviran i prezentiran za javnost. (sl. 4).

\footnotetext{
16 M. ILIJANIĆ, Varaždinske gradske zidine, Prilog historijatu našeg grada, Urbanizam, graditeljstvo kultura, Zbornik radova, Grad Varaždin - Gradski muzej Varaždin, Varaždin 1999., 215.; M. KLEMM, n. dj., 16-17.

17 M. ŠIMEK, n. dj., 21-22.
} 


\section{SJEVERNI GRADSKI ZID}

Sjeverni gradski zid već je prilikom sustavne razgradnje u 19. st. uništen i pregrađen. ${ }^{18}$ Njegovi ostaci bili su vidljivi prilikom uređenja okoliša Starog grada 1941. godine ispred ulaza u zgradu žitnice (sl. 5). Tada je jedan segment tog zida i iskopan, a uz njegovo južno lice pronađena je ulazna kula s upisanom starijom kulom koja je srušena u 19. st. zbog opasnosti od rušenja uslijed djelovanja klizišta vodene grabe u njezinoj neposrednoj blizini. ${ }^{19}$ Ovaj segment zida ispitan je naknadno revizijskim iskopavanjem 1971. godine u svrhu arhitektonskih ispitivanja kada su provedena detaljnija mjerenja pri čemu se ustanovilo da su obje strane lica zida uništene, a debljina mu je varirala od 80 do $100 \mathrm{~cm} .{ }^{20}$

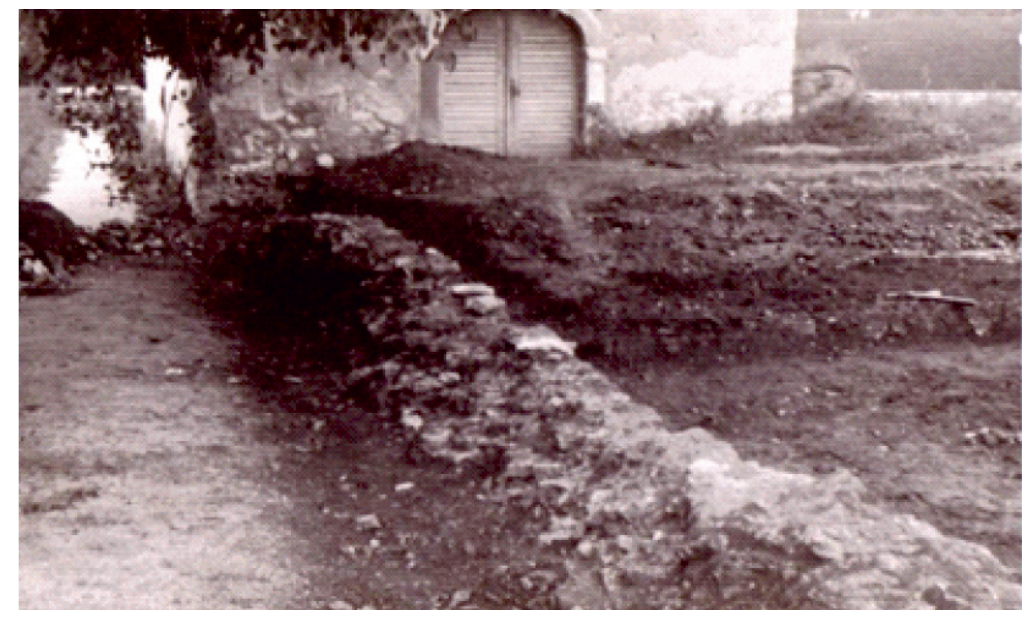

Slika 5. Ostatak sjevernog gradskog zida ispred zgrade žitnice 1941. godine (Gradski muzej Varaždin)

Danas je dio tog sjevernog gradskog zida vidljiv jedino u unutrašnjosti podrumske prostorije žitnice nakon konzervatorsko-restauratorskih radova koje provodi Hrvatski restauratorski zavod. Zid je ukorporiran u zgradu žitnice kao njezin južni zid (SI. 6), što je uostalom i vidljivo na planu Daniela Specklina. Građen je od kamena lomljenca vezanog žbukom, temeljni dio izveden je masivnijim blokovima širine $115 \mathrm{~cm}$, dok se na katu zgrade njegova širina smanjuje na $90 \mathrm{~cm}$, a

18 M. MIRKOVIĆ, n. dj., 49.

19 K. FILIĆ, n. dj., 25-26.

20 Ivan ZDRAVKOVIĆ, Iskopavanja Stari grad - tvrdja 1971. god., Jugoslavenski institut za zaštitu spomenika kulture, Beograd, 1971. (GMV AO dokumentacija). 
sukladno tome i kameni blokovi postaju manji. Budućim konzervatorsko-restauratorskim istraživanjima na zgradi žitnice i na tom segmentu zida možda će se otkriti više podataka o pojedinim građevinskim elementima koji bi bili zanimljivi za usporedbu s likovnim prikazima i povijesnim izvorima. Linija sjevernog gradskog zida kreće od smjera žitnice prema Bakačevoj ulici (platea muri civitatis) ${ }^{21}$ gdje su arheološki potvrđeni ostaci zida i dijela sjeveroistočne kule. Temeljni dio zida pronađen 2003. godine (sl. 7) u Bakačevoj ulici kbr. 2 prema načinu gradnje pokazuje sličnost s prethodno opisanim ostacima gradskih zidina. Građen od kamena lomljenca vezanog žbukom pozicioniran je u smjeru istok-zapad, najveće je do sada zabilježene širine od $160 \mathrm{~cm}$, sačuvan u visini od $80 \mathrm{~cm}$. Temelji zida u istoj ulici potvrđeni su na još dvije pozicije arheološkim nadzorom 1996. godine, a osim njih pronađen je i ostatak poligonalne sjeveroistočne kule na uglu Bakačeve i Šenoine ulice ispod nekadašnje zgrade Tive. ${ }^{22}$ Jedini danas još uvijek sačuvan dio sjevernog obrambenog sklopa predstavljaju sjeverna ili bečka gradska vrata (Porta civitatis superior), tzv. Lisakova kula.

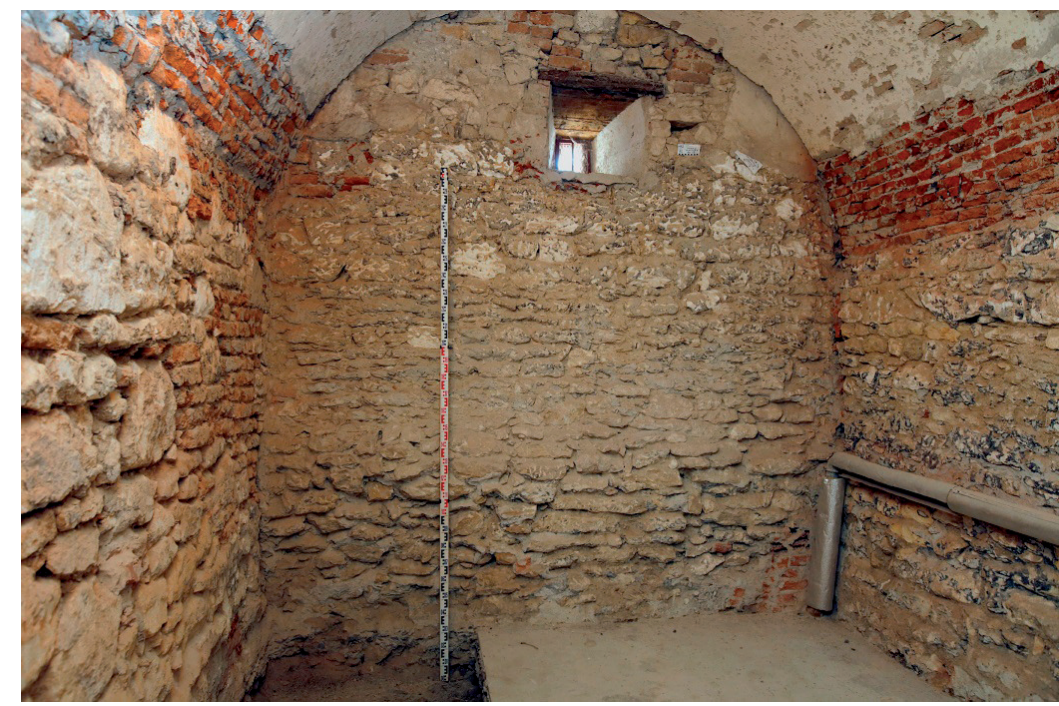

Slika 6. Ostatak sjevernog gradskog zida u zgradi žitnice

(snimio: Andrej Švoger. Gradski muzej Varaždin)

21 Adolf WISSERT, "Bilješke o nekim varaždinskim kućama”, Spomenica Varaždinskog muzeja 19251935, Varaždin, 1995., 42.

22 M. ŠIMEK, Izvještaj o arheološkom istraživanju - Varaždin Bakačeva ul. 2, 2003.; M. ŠıMEK, Izvještaj o arheološkom nadzoru u Bakačevoj i Padovčevoj ulici, 1996. (GMV AO dokumentacija); M. MIRKOVIĆ, n.dj. 48.; Iz troškovnika koji je bio priložen karti koju je 1807. g. izradio Ignacije Beyschlag sve gradske kule, s izuzetkom jedne za koju nije navedena namjena, u 19. st. su bile u određenoj funkciji. 


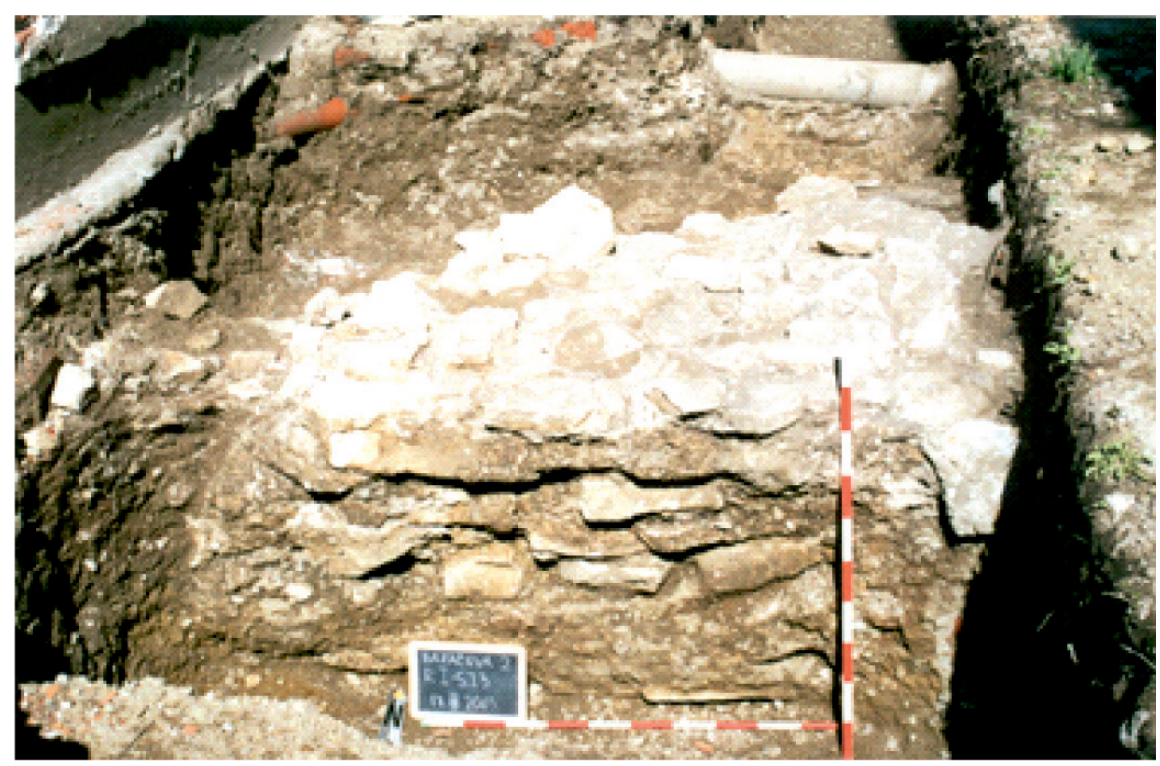

Slika 7. Ostatak sjevernog gradskog zida 1996. godine (snimila: Marina Šimek. Gradski muzej Varaždin)

\section{ISTOČNI GRADSKI ZID}

Na sjecištu Stepinčeve i Habdelićeve ulice pronađen je prilikom arheološkog nadzora 2015. godine temeljni dio istočnog gradskog zida u iskopu za vodovodni šaht. ${ }^{23}$ Kako se južno od vodovodnog rova nalazio kanalizacijski rov u kojem nije pronađeno nikakvih arheoloških struktura, ovaj zid bio je iznenađenje (sl. 8). Pronađen je na dubini od $150 \mathrm{~cm}$ položen u smjeru sjever - jug, debljine otprilike $110 \mathrm{~cm}$.

23 Ivančica PEHARDA, Varaždin-Ulica Juraja Habdelića, Izvještaj o arheološkom nadzoru, 2015., (GMV AO dokumentacija). 


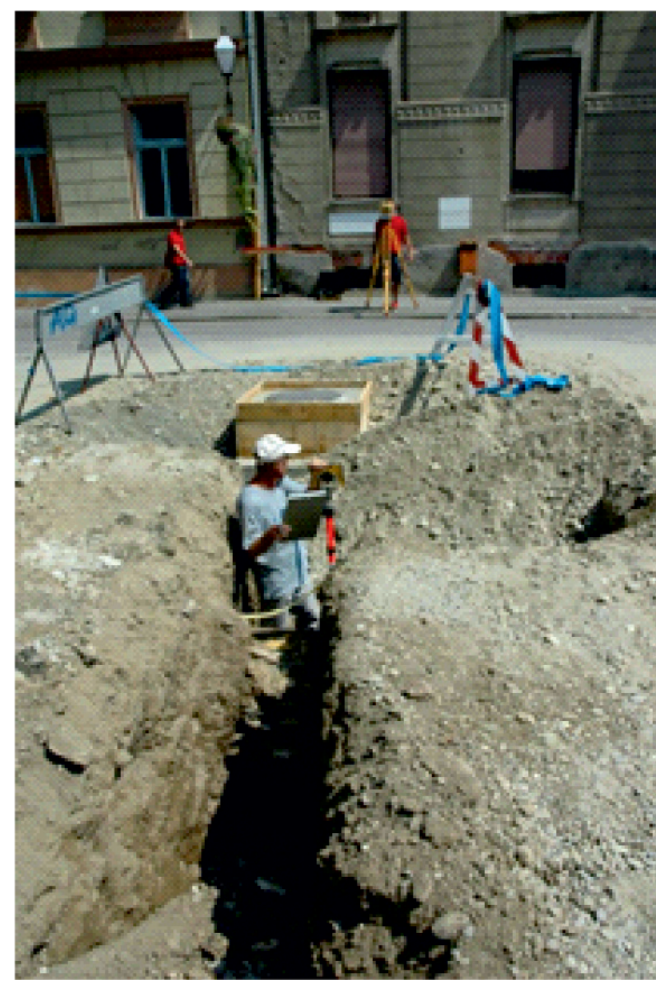

Slika 8. Geodetska izmjera istočnog gradskog zida 2015. godine (snimila: Lovorka Štimac-Dedić. Gradski muzej Varaždin)

Stanje zida u kojem je pronađen bilo je loše, a dodatno je na njegovoj sačuvanoj gornjoj površini ranijim infrastrukturnim radovima bez arheološkog nadzora postavljena cijev. Uslijed brzine radova koje su diktirali rokovi, zid nije bilo moguće detaljno ispitati. Ono što je bilo izvjesno je njegova tvrdoća zbog koje su uostalom i ostavljeni temeljni dijelovi gradskih zidina ispod razine današnjih ulica jer materijal nakon razbijanja nije bio pogodan za sekundarnu upotrebu. ${ }^{24}$ Ovaj nalaz temelja zida važan je za točno praćenje pravca gradskih zidina, a istovremeno je jedini dio od sve četiri strane gradskih zidina koji do sada nije bio

24 M. MIRKOVIĆ, n. dj., 46-50. 
potvrđen. Njegov pronalazak olakšati će lociranje ugaone kule koja se nalazila na sjecištu južnog i istočnog gradskog zida (sl. 9), a u kojoj se još u 19. st. nalazila slastičarnica. ${ }^{25}$

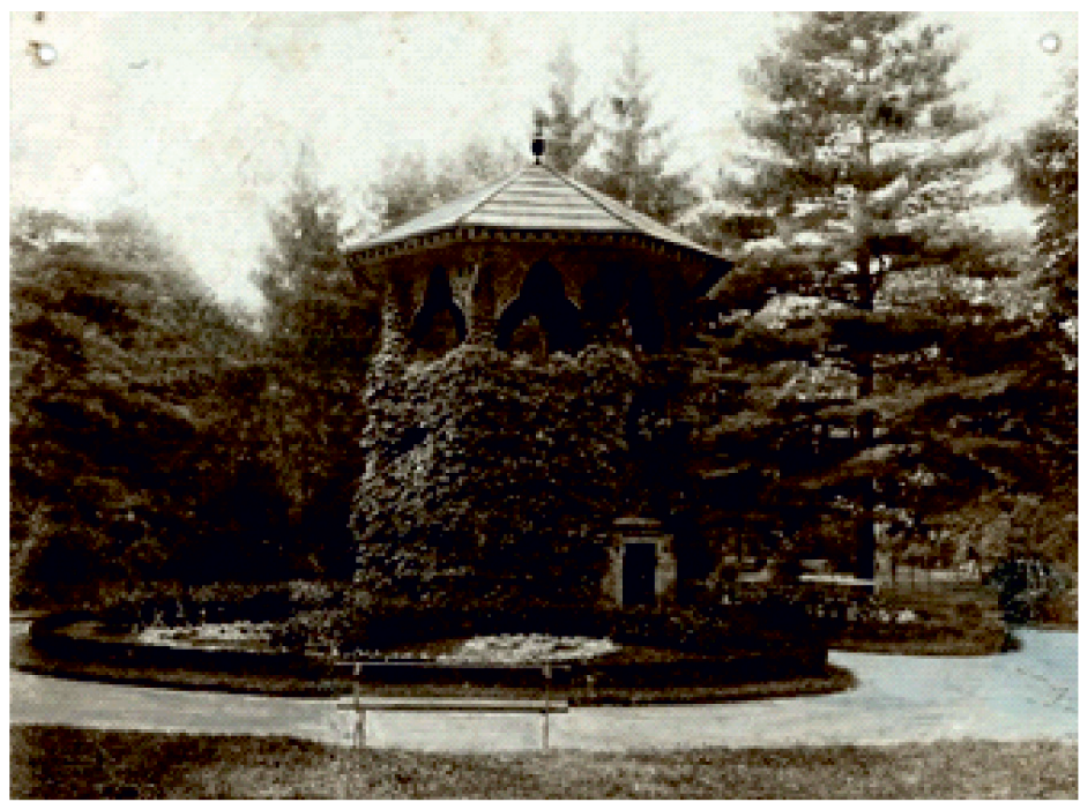

Slika 9. Jugoistočna kula u gradskom parku u 19. st. (Gradski muzej Varaždin)

\section{JUŽNI GRADSKI ZID}

Južni gradski zid do sada nije otkriven arheološkim nadzorom. Dio tog zida ostao je sačuvan u temeljima jedne od kuća na Trgu slobode u blizini nekadašnjih južnih ili zagrebačkih vrata ("Porta civitatis inferior") srušenih iza 1830. godine. Vedute koji grad pokazuju s južne strane prikazuju promjene u izgledu vrata, a nacrti kuća uz vrata krajem 18. st. omogućuju djelomičan uvid u njihov tadašnji izgled te tlocrtnu poziciju ostatka gradskog zida. ${ }^{26}$ Segment južnog gradskog zida danas vidljiv u podrumskom dijelu kuće na Trgu slobode širine je oko $160 \mathrm{~cm}$, a na njemu su izvedene razne intervencije i dogradnje instalacija (SI. 10).

25 S. TEŽAK, n. dj., 266.

26 I. LENTIĆ-KUGLI, "Južna ili Zagrebačka vrata odnosno Porta civitatis inferior u Varaždinu”, Godišnjak gradskog muzeja Varaždin 8, 1988., 15-17. 


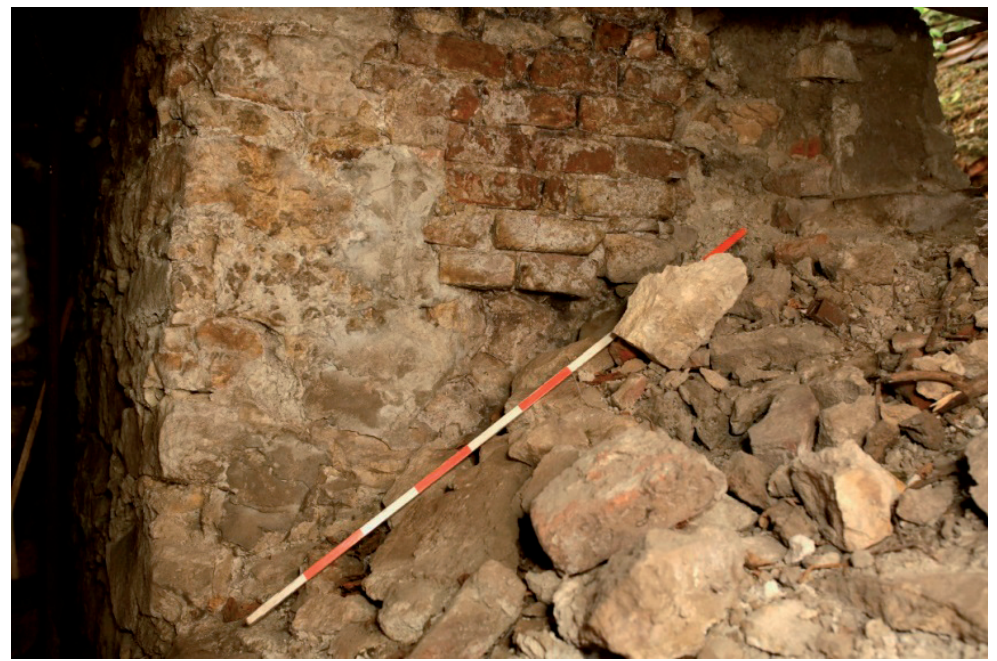

Slika 10. Ostatak istočnog gradskog zida (snimio: Andrej Švoger. Gradski muzej Varaždin)

\section{ZAKLJUČAK}

Arheološki nadzori provedeni nad gradskim zidinama još uvijek predstavljaju premali postotak istraženosti kako bi se mogli izvući konkretniji zaključci i usporedbe s povijesnim izvorima i slikovnim prikazima. Bez obzira na te oskudne podatke, slika postaje ipak nešto jasnija. Potvrđene su sve četiri strane utvrda oko naselja koje pokazuju zajedničke značajke građevinskih elemenata. Doznaju se podaci o načinu gradnje, o temeljnim dijelovima koji su bili vrlo čvrsto građeni, najveće zabilježene širine u temeljnom dijelu od $160 \mathrm{~cm}$ pa do prosječne širine u gornjim dijelovima zidova od $90 \mathrm{~cm}$, što uostalom i odgovara povijesnim izvorima koji navode dimenzije širine od pola hvata. Podatak o sve četiri strane gradskih zidina važan je za daljnje planiranje arheoloških i geofizičkih istraživanja kojima bi se točno ocrtale njihove linije, a u svrhu neke od budućih prezentacija. Treba pričekati koje će spoznaje donijeti buduća arheološka istraživanja na području grada te nastavak konzervatorsko-restauratorskih radova na segmentu sjevernog zida u zgradi Žitnice. 


\section{LITERATURA}

1/ Rudolf HORVAT, Povijest grada Varaždina, Hrvatska akademija znanosti i umjetnosti, Zavod za znanstveni rad Varaždin, Varaždin, 1993.

2/ Mira ILIJANIĆ, "Prilog istraživanju renesansne pregradnje varaždinske tvrđe u 16. stoljeću", Godišnjak Gradskog muzeja Varaždin, br. 1, Varaždin, 1961. str. 33-43.

3/ Mira ILIJANIĆ, „Prilog historijsko urbanističkoj dokumentaciji Varaždina od postanka do 16. st.", Peristil: Zbornik radova za povijest umjetnosti, Vol. 6-7, No. 1, Zagreb, 1963., str. 23-27.

4/ Mira ILIJANIĆ, Urbanizam, graditeljstvo kultura, Zbornik radova, Varaždin, 1999.

5/ Miroslav KLEMM, Marina ŠIMEK, Spomenka TEŽAK, Iz srednjega u novi vijek - varaždinski Stari grad i projekt Bastion, Katalog izložbe, Varaždin, 2008.

6/ LENTIĆ-KUGLI, Ivy, Povijesna urbana cjelina grada Varaždina, Zagreb, 1977.

7/ Ivy LENTIĆ-KUGLI, "Južna ili Zagrebačka vrata odnosno Porta civitatis inferior u Varaždinu”, Godišnjak gradskog muzeja Varaždin 8, Varaždin, 1988., 13-18.

8/ Marija MIRKOVIĆ, "O spajanju unutarnje varoši i gradskih predgrađa u Varaždinu", Godišnjak Gradskog muzeja Varaždin, br. 2-3, Varaždin, 19621963., str. 42-66.

9/ Ljerka PERČI, "Prilog poznavanju izgradnje varaždinskih gradskih utvrđenja u prvoj četvrtini 16. stoljeća”, Muzejski vjesnik 12, Bjelovar, 1989. str. 54-56.

10/ Mirela SLUKAN ALTIĆ, "Razvoj i gradnja Varaždina u 16. st., Urban development of Varaždin in the 16th century", Podravina Volumen VII, broj 14, Koprivnica, 2008., str. 75-88.

11/ Mirela SLUKAN ALTIĆ, Povijesni atlas gradova, Varaždin, V. svezak, Zagreb Varaždin, 2009.

12/ Marina ŠIMEK, “Arheološka istraživanja varaždinske utvrde”, Podravina Vol. VII, br.13, Koprivnica, 2008., STR. 5-21.

13/ Spomenka TEŽAK, "Varaždinska gradska utvrđenja", Izdanja Hrvatskog arheološkog društva, Vol 28, Zagreb, 2012., str. 259-274.

14/ Andrej ŽMEGAČ, Bastioni kontinentalne Hrvatske, Institut za povijest umjetnosti, Zagreb, 2000.

15/ Adolf WISSERT, Spomenica Varaždinskog muzeja 1925-1935, Varaždin, 1995. 


\section{DOKUMENTACIJA GRADSKOG MUZEJA VARAŽDIN}

1/ Ivančica PEHARDA, Varaždin-Ulica Juraja Habdelića, Izvještaj o arheološkom nadzoru, Varaždin, 2015.

2/ Marina ŠıMEK, Izvještaj o arheološkom istraživanju - Varaždin Bakačeva Ul.2, Varaždin, 2003.

3/ Marina ŠIMEK, Izvještaj o arheološkom nadzoru u Bakačevoj i Padovčevoj ulici, Varaždin, 1996.

4/ Marina ŠIMEK, Varaždin - Stari grad, arheološko istraživanje 2006., Varaždin, 2007.

5/ Krešimir FILIĆ, Blagajnička knjiga Povjereničtva za službu rada mladosti, Varaždin, 1941.

6/ Stjepan VUKOVIĆ, Knjiga bilješki/Terenski dnevnik, Varaždin.

7/ Ivan ZDRAVKOVIĆ, (1971), Iskopavanja Stari grad - tvrdja 1971. god., Jugoslavenski institut za zaštitu spomenika kulture, Beograd.

\section{SAŽETAK}

\section{ARHEOLOŠKA I POVIJESNA ISTRAŽIVANJA VARAŽDINSKIH UTVRDA}

Utvrde oko naselja okruživale su grad Varaždin u obliku nepravilnog četverokuta s bastionima, polukružnim kulama te sjevernim i južnim gradskim vratima u koje se preko opkopa ulazilo drvenim mostovima. Njihov nastanak, prema do sada poznatim povijesnim izvorima, veže se uz opasnosti koje su prijetile širem području Hrvatskog kraljevstva i Štajerskoj u drugoj polovici 15. st., dok je srednjovjekovni fortifikacijski supstrat na kojem utvrde nastaju do sada još uvijek nedovoljno istražen. Točan početak njihove gradnje za sada predstavlja nepoznanicu, a podaci u povijesnim izvorima spominju postojanje i gradnju zidina već od 1516. godine. Neki elementi koji naslućuju izgled utvrda oko naselja prije modernizacije poznati su iz povijesnih izvora, ali svoju konačnu preobrazbu oni su dostigli svakako tijekom renesansne obnove plemićke utvrde u Wasserburg kada su ta dva elementa povezana zajedničkim fortifikacijskim sustavom. Nakon tog razdoblja, osim popravaka na utvrdi oko naselja nije bilo značajnijih intervencija do druge polovice 18. st. kada se probijaju zidovi na istočnoj i zapadnoj strani zbog urbanističkog razvoja grada i olakšavanja prometnog kretanja. Početkom 19. st. utvrde su sustavno razrušene, s ostavljenim tek temeljnim dijelovima zidina ispod ulične razine i pojedinim segmentima u temeljima kuća. Arheološkim nadzorom potvrđeni su ostatci sjevernog i istočnog dijela gradskog zida, zapad- 
ni gradski zid ispitan je sustavnim arheološkim istraživanjem u sklopu projekta Bastion, dok se novijim konzervatorsko-restauratorskim istraživanjem na zgradi žitnice otkrio ostatak sjevernog gradskog zida koji istovremeno čini južni zid zgrade. Južni gradski zid jedini je koji do sad nije obuhvaćen arheološkim nadzorom, ali je vidljiv u temelju jedne od kuća na Trgu Slobode. Svi ostaci gradskih zidina pokazuju zajedničke građevinske značajke, a činjenica da su detektirani na sve četiri strane rasprostiranja, olakšati će bilo kakvu vrstu buduće rekonstrukcije u svrhu prezentacije. Kako se radi o vrlo malom postotku istraženosti u odnosu na površinu kojom su se gradske zidine rasprostirale, za sve nove spoznaje treba pričekati buduća arheološka istraživanja na području grada Varaždina.

Ključne riječi: grad Varaždin; gradska arheologija; varaždinske utvrde.

\section{SUMMARY \\ ARCHAEOLOGICAL AND HISTORICAL RESEARCH OF THE VARAŽDIN FORTRESS}

The town of Varaždin was surrounded by a fortification in the shape of an irregular quadrilateral with bastions, semi-circular half towers and north and south town gates which were entered across wooden bridges stretching over a moat. According to historical sources, its construction was associated with the impending threat to the wider area of the Kingdom of Croatia and Styria in the second half of the 15th century, while the underlying mediaeval fortification layer that preceded it has not been sufficiently researched yet. Although the exact time of the beginning of its construction remains unknown, the existence and construction of the walls is mentioned in the sources as early as 1516. Some elements indicating the appearance of the fortification around the settlement before it was modernised are known from historical sources, but its final transformation occurred in the Renaissance during the restoration of the feudal fortification into a Wasserburg, when these two elements were connected with a shared fortification system. Apart from repairs, after this period there were no significant interventions on the fortification until the second half of the 18th century, when the east and west walls were breached for the purpose of urban development and to facilitate transport. At the beginning of the 19th century the fortification was systematically demolished, leaving only the foundations of the walls beneath the street level and individual segments in the foundations of 
houses. In the course of archaeological supervision, the existence of the remains of the north and east part of the town wall was confirmed, the west wall was investigated in systematic archaeological research as part of the Bastion project, while the recent conservation-restoration research of the granary revealed the remains of the north town wall, which constitutes the south wall of the granary. The south town wall is the only wall that has not yet been included in archaeological supervision, but it is visible in the foundation of a building in Sloboda Square. All remains of the town walls share the same construction features and the fact that the segments of all four sides of the walls were detected will facilitate any kind of future reconstruction for presentational purposes. Since the percentage of researched segments is very small compared to the overall surface occupied by the town walls, only future archaeological research in Varaždin can provide new insights on the subject.

Key Words: town of Varaždin; urban archaeology; Varaždin fortress. 